\title{
Trade Openness, Financial Development, and Economic Growth in Turkey: Linear and Nonlinear Causality Analysis
}

\author{
Prof. Dr. Muhsin Kar (Necmettin Erbakan University, Turkey) \\ Assoc. Prof. Dr. Şaban Nazlıŏlu (Pamukkale University, Turkey) \\ Asst. Prof. Dr. Hüseyin Ağır (Sütçü İmam University, Turkey)
}

\begin{abstract}
This paper aims at empirically investigating the direction of causality among trade liberalization, financial development, and economic growth in Turkey. By employing monthly data for the period January, 1989November, 2007, both linear and nonlinear causality approaches indicate that (i) there is bi-directional causality between economic growth and trade openness, (ii) economic growth causes financial development, and (iii) financial development leads to trade liberalization. Thereby, linear and nonlinear approaches confirm strong causal linkages among financial development, trade openness, and economic growth in Turkey. These results partially imply that economic growth depends upon trade liberalization through external finance in Turkey which has been experiencing capital account liberalization since 1989.
\end{abstract}

\section{Introduction}

It has been theoretically argued that both trade liberalization and financial development may play a crucial role in economic development. Trade liberalization reduces inefficiency in the production process and financial development facilitates the intermediation between savers and investors. Thus, they have a great deal of potential to positively influence economic growth in the developing countries. The theoretical and empirical studies mainly concentrate on either the relationship between trade and growth or the association between finance and growth. However, until recently, the empirical linkages between trade liberalization and financial development have not received sufficient attention in the literature.

Turkey has been implementing trade oriented development strategy since 1980 and has been experiencing financial liberalization process since 1989. Nevertheless, even though Turkey had faced to serious economic turbulences in 1994 and in the early 2000, she has recorded an impressive growth performance during the last decade. These dynamics of the Turkish economy provide us room to examine the nature of causal linkages between trade openness, financial development, and economic growth. To best of our knowledge, there is not any study on this subject for Turkey and thereby identifying the causal linkages among the variables of interest is timely and important to design financial system and trade policies for sustainable development.

The aim of this paper, therefore, is to econometrically investigate direct linkages among trade liberalization, financial development and economic growth for Turkey by employing monthly data for the period January, 1989- November, 2007. In particular, this work tries to empirically find an answer for the question of whether financial development leads trade liberalization or of whether trade liberalization leads financial development in Turkey in a trivariate framework by including economic growth which is interrelated with both trade openness and financial development. In addition to linear causality analysis, we carried out the nonlinear causality test in order to see whether the causal linkages among the variables of interest is sensitive the structural shifts and asymmetries in the series. In brief, we find from both linear and nonlinear approaches that financial development is the cause of trade liberalization and there is bi-directional causality between economic growth and trade openness and between economic growth and financial development. Thereby, linear and nonlinear approaches confirm strong causal linkages among financial development, trade openness, and economic growth in Turkey.

The novelty of this study is three-fold. First, this paper is the first that employs monthly income data in the literature on the finance-growth nexus for Turkey. Second, we conduct the financial development index -that is good able to capture of different dimensions of financial development- by means of principal component analysis. Third, in addition to linear causality analysis, we conduct nonlinear causality tests in order to determine whether there are asymmetric causal linkages between trade openness, financial development, and economic growth in Turkey.

\section{Theoretical Framework and Empirical Evidence}

The impacts of trade liberalization and financial development on economic growth have increasingly obtained a significant attraction in the literature. It is argued that both policy instruments fasten economic growth in the developing economies through various channels. Trade liberalization by allowing the allocation of factors of production across sectors (Grossman and Helpman, 1992; Redding, 1997), by increasing the competition in the domestic economy and hence improving productivity (Greenaway and Milner, 1993; Aghion, Dewatripont and Rey, 1997), by enlarging the market for domestic producers and leading to take advantage of the economies of scale (Taylor, 1994; Grossman and Helpman, 1991), by increasing number of inputs that have no domestic 
substitutes and thus leading to a higher capacity utilization (Nishimizu and Robinson, 1986; Quah and Rauch, 1990; Grossman and Helpman, 1992) and, finally by letting the flow of knowledge across sectors and countries (Feder, 1982; Grossman and Helpman, 1992) might positively influence economic growth.

In fact, the role of financial sector on economic growth has long debated in the literature. Schumpeter (1912), one of the earliest pioneers, emphasized the importance of finance for growth. In the same line, Patrick (1966) introduced two new concepts which highlight the demand and supply side conditions, namely demand-following and supply-leading hypothesis. While the former states that demand in the real sector is the engine for creation of financial services, the latter emphasizes that supply in the financial sector is the driving force behind the development of real sector. Patrick's (1966) argument brought about the discussion whether the direction of causality from finance to growth or vice versa.

The literature moved to highlight the importance of mobilization of domestic resources in the early $1970 \mathrm{~s}$. Specifically, McKinnon (1973) and Shaw (1973) suggested the liberalization in the financial sector in terms of lifting any sort of restrictions in the sector. They argued that lack of saving is a widespread phenomenon rather than lack of investment in the developing countries. Therefore policies should focus on increase in saving through a positive real interest rate policy.

With the emergence of endogenous growth theory (Romer, 1986) in the mid-1980s, it is argued that financial development might be one of the sources for the increase rate of return (Renelt, 1991). Financial development by increasing the possibility of choosing more productive investments through improved management of liquidity risks (Bencivenga and Smith 1991), by collecting information on the efficiency of various investment projects and/or investors' abilities (Greenwood and Jovanovic, 1990; King and Levine 1993) and by diversifying more efficiently investors' portfolios (Levine, 1991; Saint-Paul, 1992) might positively contribute to economic growth (Levine, 1997). These arguments based on endogenous growth theories implicitly assume that financial development promotes economic growth (Hermes, 1994).

The literature, in the 2000s, started to focus on the determinants of financial development. In order to understand the dynamics of the differences in the level of financial development, several factors are proposed for this purpose: Legal origin (La Porta et.al., 1997; Demetriades, 2008), public bank ownership (La Porta et.al., 2002; Andrianova et.al., 2008; Demetriades, 2008), initial conditions and institutional structure (Acemoglu et.al., 2001, 2004; Demetriades, 2008), trade liberalization (Rajan and Zingales, 2003; Do and Levchenko, 2006; Huang, 2006; Demetriades, 2008; Law, 2008, 2009), capital account liberalization (Chinn and Ito, 2002, 2006; Law and Demetriades, 2006; Klein and Olivei, 2008), prudential supervision and effective regulation (Cuadro et.al., 2003; Brownbridge et.al., 2005), deposit insurance (Cull et.al., 2001), required reserves (Di Giorgio, 1999; Arestis et.al., 2002) and macroeconomic policies (i.e. Inflation, exchange rate) (Montiel, 2003; Cuadro et.al., 2003; Bittencourt, 2008; Ben Naceur et.al., 2008).

Although the theoretical literature assumes linkages both between trade liberalization and economic growth and between finance and growth, the multi causal linkages between economic growth, financial development, and international trade has recently attracted attention. Rajan and Zingales (2003) emphasize the role of the supply-side factors and the resistance of incumbent industrialists and domestic financial intermediaries who have a vested interest in a closed financial sector and therefore oppose the developments in the financial market. It is argued that these incentives may be weakened with the opening domestic financial sector to foreign competition and to international flows of capital.

On the contrary, Svaleyrd and Vlachos $(2000,2002)$ highlight the importance of the demand-side factors and the possibility of risk diversification with the trade liberalization which creates new demands for external finance. This external resource for firms is a necessity to overcome short-term cashflow problems and adverse shocks.

In order to fill the theoretical gap for the linkages among trade openness, financial development, and economic growth in a multi causal conceptual framework, Blackburn and Hung (1998) suggest that trade liberalization by leading new product development may contribute to economic growth. Financial development may be resulted from trade liberalization which encourages the number of new producers who need access to finance their activities. Similarly, Feeney (1994) argues that integration in the financial sector may enhance the probability for risk sharing that allows product specialization and, in turn, benefits trade. These studies imply an indirect theoretical link between trade liberalization and financial development via new products.

In sum, the above reviewed studies fall short of establishing direct linkages between trade liberalization and financial development. Ginebri et. al. (2001) emphasize the issue of complementarity between trade and finance and propose a direct relationship between trade liberalization and financial development. In particular, the complementarity is theoretically based upon the fact that trade liberalization enhances entrepreneurial development which in turn increases a need of new instrument from the financial system.

The relationship between trade liberalization and financial development has been a subject matter for a limited number of empirical works which provide evidences for the argument that trade liberalization is a crucial step to enhance financial development and/or vice versa in a single country or a group of countries (Beck, 2002; 
Svaleyrd and Vlachos, 2000, 2002; Rajan and Zingales, 2003; Do and Levchenko, 2004; Huang and Temple, 2005; Hur, Raj and Riyanto, 2006; Bao and Yang, 2007; Law, 2008, 2009; Baltagi et.al., 2009; Das and Rishi, 2010). In contrast, Gries, Kraft and Meierrieks (2009) find a limited support for the finance-led growth and financial deepening and trade openness have swayed economic development rather marginally.

As far as the empirical works for Turkey are concerned, there is not any consensus on the direction of causality not only between trade and growth (Ghatak, Milner and Utkulu, 1995; Bahmani-Oskooee and Domac, 1995; Yiğidim and Köse, 1997; Özmen and Furtun, 1998; Doğanlar and Fisunoğlu, 1999; Özmen et. al, 1999; Hatemi-J ve Irandoust, 2000; Tuncer, 2002; Şimşek, 2003; Bilgin and Şahbaz, 2009) but also between finance and growth (Şıklar, 1992; Akçoraoğlu, 2000; Kar and Pentecost, 2000; Doğan, 2002; Ünalmış, 2002; Aslan and Korap, 2006; Aslan and Küçükaksoy, 2006; Kar and Ağır, 2006; Acaravc1, 2007; Halıcığlu, 2007; Öztürk, 2008; Yücel and Altıntaş, 2009). The results imply that the selection of both variables and the methodology determines the direction of causality between the concerned variables in these empirical works.

There is a limited work which concentrates on the relationship between finance and trade for Turkey. Utkulu ve Kahyaoğlu (2005) examines the impacts of both financial and trade openness on economic growth and find that while financial openness negatively contributes to economic growth, trade liberalization has a positive effect on growth in Turkey. Açıkgöz, Balcılar and Saraçoğlu (2009) also investigate the causal linkages among financial development, financial openness and trade openness by employing bounds test developed by Pesaran et.al. (2001) and Pesaran and Shin (1999) for the period 1989:Q1-2007:Q2 and provide empirical evidence that both financial and trade openness have a positive impact on financial development for Turkey. Kar, Peker and Kaplan (2008) examines a long-run relationship between trade liberalization, financial development and economic growth for the period 1963-2005 in Turkey and concludes that openness and finance has a positive impact on growth in the long-run. Yücel (2009) finds a bi-directional causality between each pair of the variables, namely financial development (measured by the broad money to GDP ratio), trade and economic growth, for the period 1989M1-2007M11 in Turkey. Ağır (2010) provides empirical evidence that trade, among other variables, plays a significant role in explaining financial development in Turkey.

\section{Econometric Methodology}

\subsection{Linear Granger Causality Test}

The standard Granger causality test requires carrying out zero restrictions on coefficients in Vector Autoregressive (VAR) model based on the Wald principle. Wald test for Granger causality may result in nonstandard limiting distributions based on the cointegration properties of the system and possibly on nuisance parameters. These nonstandard asymptotic properties are due to the singularity of the asymptotic distributions of the estimators (Lütkepohl, 2004: 148). Toda and Yamamoto (TY) (1995) developed the modified Wald (MWALD) test for Granger causality which overcomes this singularity problem.

The standard Granger causality analysis is based on estimating a VAR $(p)$ model. In order to correct the singularity problem TY (1995) suggest using a VAR $(p+d)$ model in which $d$ is the maximum integration degree of the variables. The following VAR model is therefore estimated in the TY procedure:

$$
y_{t}=v+A_{1} y_{t-1}+\cdots+A_{p} y_{t-p}+\cdots+A_{p+1} y_{t-p-d}+\mu_{t} .
$$

where $\mathrm{y}_{\mathrm{t}}$ is vector of k variables, $v$ is a vector of intercepts, $\mu_{t}$ is a vector of error terms and $A$ is the matrix of parameters. To test for the null of no-Granger causality against the alternative hypothesis is tested by imposing zero restriction on the first $p$ parameters in equation (1). The MWALD statistic has asymptotic chi-square distribution with $p$ degrees of freedom irrespective of the number of unit roots and the cointegrating properties.

Hacker and Hatemi-J (2006) investigate the size properties of the MWALD test and find that the test statistic with asymptotic distribution poorly performs in small samples. Monte Carlo simulation of Hacker and Hatemi-J (2006) shows that the MWALD test based on the bootstrap distribution has much smaller size distortions than those of the asymptotic distribution. Hacker and Hatemi-J (2006:1492-1493) extends the TY approach based on the bootstrapping method developed by Efron (1997). In this new approach that is so-called the leveraged bootstrap Granger causality test, the MWALD statistic are compared with the bootstrap critical value instead of the asymptotic critical value.

\subsection{Nonlinear Granger Causality Test}

The linear Granger causality test does not account for nonlinear causal relationships among the variables. The Monte Carlo study of Baek and Brock (1992) demonstrates that in the presence of nonlinearity, the forecasting performance of nonlinear approach is better than that of linear modelling. In order to test for the null of nonlinear non-Granger causality, the nonparametric test of Hiemstra and Jones (HJ) (1994) is widely employed. However, the HJ test may over rejects the null hypothesis in the case of increasing sample size, which is stemming from ignoring the possible variations in conditional distributions (Diks and Panchenko, 2005). The nonlinear causality test recently developed by Diks and Panchenko (DP) (2006) overcomes this drawback of the HJ test. 
DP (2006) offer the following statistic to test for nonlinear Granger causality.

$$
T_{n}\left(\varepsilon_{n}\right)=\frac{n-1}{n(n-2)} \sum_{i}\left(\hat{f}_{X, Y, Z}\left(X_{i}, Y_{i}, Z_{i}\right) \hat{f}_{Y}\left(Y_{i}\right)-\hat{f}_{X, Y}\left(X_{i}, Y_{i}\right) \hat{f}_{Y, Z}\left(Y_{i}, Z_{i}\right)\right)
$$

where $\hat{f}_{W}\left(W_{i}\right)$ is a local density estimator of a $\mathrm{d}_{\mathrm{w}}-$ variate random vector $\mathrm{W}$ at $\mathrm{W}_{\mathrm{i}}$ defined by $\hat{f} w\left(W_{i}\right)=\left(2 \varepsilon_{n}\right)^{-d_{W}}(n-1)^{-1} \sum_{j j \neq i} \mathrm{I}_{i j}^{w}$ that $\mathrm{I}_{i j}^{w}=\mathrm{I}\left(\left\|W_{i}-W_{j}\right\|<\varepsilon_{n}\right)$ with the indicator function $\mathrm{I}($.$) and$ the bandwidth $\varepsilon_{n}$. For one lag (i.e. $\left.l x=l y=1\right)$, if $\varepsilon_{n}=C n^{-\beta}\left(C>0, \frac{1}{4}<\beta<\frac{1}{3}\right)$, the test statistic is asymptotically distributed as standard normal. Since the statistic diverges to positive infinity under the alternative hypothesis, the calculated statistic greater than 1.28 implies the rejection of the null hypothesis at 10 percent level of significance.

In the DP test, value of the bandwidth plays an important role in making a decision on nonlinear causality. Since the bandwidth value smaller (larger) than one generally results in larger (smaller) $p$-value (Bekiros and Diks, 2008: 1646), the bandwidth value is equal to one in this study.

\section{Data}

This paper employs monthly observation for the variables for the period 1989:M1-2007:M11 in Turkey. In particular, the Turkish Statistical Institute has provided a quarterly GDP series since 1986 and there is not a monthly data for this variable. The monthly real GDP series used in the analysis is generated by Taşdemir (2008) by utilizing steady-space approach. The time span for income series (monthly real GDP) restricts the range of other series employed in the analysis.

Trade openness (TO) is measured as the ratio of total trade (exports plus imports) to the GDP as a proxy for trade liberalization. Data for trade openness and financial development indicators are respectively collected from the on-line database of TurkStat (Turkish Statistical Institute) and of the Central Bank of Turkish Republic.

Financial development is a multifaceted issue and has not a direct measurement. Instead, a number of proxies to catch up various dimensions of financial development have been used in the literature. This paper develops a financial development index by utilizing principle component analysis that is a statistical tool to transform a number of correlated variables into a smaller number of uncorrelated variables (Creane et al., 2003; Saci and Holden, 2008; Jalli et al., 2010). The financial development index (FD) is constructed from the ratio of M2 to income (M2Y), the ratio of domestic credit to income (DCY), the ratio of private sector credit to income (PSCY), and the market capitalization ratio (MCR). The market capitalization ratio is measured as the ratio of stock market index to income. FD carries information not only about the monetary and credit aggregates but also capital markets.

\begin{tabular}{|c|c|c|c|c|c|}
\hline \multicolumn{6}{|c|}{ Eigenvalues: $($ Sum $=4$, Average $=1)$} \\
\hline & & & & Cumulative & Cumulative \\
\hline Number & Value & Difference & Proportion & Value & Proportion \\
\hline 1 & 2.251237 & 1.205801 & 0.5628 & 2.251237 & 0.5628 \\
\hline 2 & 1.045436 & 0.384093 & 0.2614 & 3.296673 & 0.8242 \\
\hline 3 & 0.661343 & 0.619359 & 0.1653 & 3.958016 & 0.9895 \\
\hline 4 & 0.041984 & --- & 0.0105 & 4.000000 & 1.0000 \\
\hline \multicolumn{6}{|c|}{ Eigenvectors (loadings): } \\
\hline Variable & PC 1 & PC 2 & PC 3 & PC 4 & \\
\hline PCSY & 0.648129 & -0.039295 & 0.214224 & -0.729721 & \\
\hline DCY & 0.557986 & -0.451445 & 0.325603 & 0.615493 & \\
\hline M2Y & 0.464323 & 0.162880 & -0.857189 & 0.151990 & \\
\hline MCR & 0.230184 & 0.876427 & 0.336627 & 0.256074 & \\
\hline
\end{tabular}

Table 1: Results from principal component analysis

Table 1 reports the results from principal component analysis. The eigenvalues for three principal components show that the first principal component (PC1) explains the highest proportion of variance by accounting 56.28 percent of the standardized variance. Accordingly, the financial development index is constructed by using the factor loadings based on the first principal component. 


\section{Empirical Findings}

Before proceeding with the TY and the DP procedures, the maximum integration degree (d) of the variables that are expressed in logarithmic form- are determined by three unit root tests developed by Dickey and Fuller (1979) and Phillips and Perron (1988) which test for the null of a unit root and Kwiatkowski et al. (1992) that tests for the null hypothesis of stationary. The results reported in Table 2 indicate that while the series in loglevels appear to be non-stationary and they are stationary in first-differences. The results accordingly imply that $d$ will be equal to one in the TY procedure, and the series in first-differences will be used in the DP test.

\begin{tabular}{|c|c|c|c|c|c|c|c|}
\hline Levels & & $\mathrm{ADF}$ & & PP & & KPSS & \\
\hline \multirow[t]{3}{*}{ Constant } & FD & -0.68 & & -0.69 & & 0.67 & $* * *$ \\
\hline & TO & -0.91 & & -3.43 & $* *$ & 1.67 & $* * *$ \\
\hline & GDP & -0.63 & & -0.68 & & 1.88 & \\
\hline \multirow{3}{*}{$\begin{array}{l}\text { Constant } \\
\text { And trend }\end{array}$} & FD & -1.54 & & -1.51 & & 0.14 & $*$ \\
\hline & TO & -2.94 & & -8.09 & $* * *$ & 0.10 & \\
\hline & GDP & -3.11 & & -4.99 & $* * *$ & 0.15 & \\
\hline \multicolumn{8}{|c|}{ First Differences } \\
\hline \multirow[t]{3}{*}{ Constant } & FD & -17.76 & $* * *$ & -17.57 & $* * *$ & 0.19 & \\
\hline & TO & -5.06 & $* * *$ & -37.13 & $* * *$ & 0.21 & \\
\hline & GDP & -24.08 & $* * *$ & -31.25 & $* * *$ & 0.28 & \\
\hline \multirow{3}{*}{$\begin{array}{l}\text { Constant } \\
\text { And trend }\end{array}$} & FD & -17.83 & $* * *$ & -17.68 & $* * *$ & 0.07 & \\
\hline & TO & -5.05 & $* * *$ & -37.06 & $* * *$ & 0.21 & \\
\hline & GDP & -24.03 & $* * *$ & -31.73 & $* * *$ & 0.29 & \\
\hline
\end{tabular}

Table 2: Results for unit root tests

The results for linear causality analysis are illustrated in Table 3. Since the TY procedure is based on ordinary least squares estimator, one need to justify the validity of assumption of that estimator. In that respect, we carry out a diagnostic checking procedure. The Breusch-Godfrey's serial correlation test implies that the residual of the estimated models are free from auto correlation problem. The Ramsey's model miss-specification test clearly shows that the functional forms of the models are appropriately specified. The White's heteroscedasticity and Engel's autoregressive conditional heteroscedasticity $(\mathrm{ARCH})$ tests indicate the validity of homoscedasticity assumption.

\begin{tabular}{|l|l|l|l|l|l|}
\hline & & \multicolumn{3}{|l|}{ Critical Value } \\
\hline & MWALD & & $1 \%$ & $5 \%$ & $10 \%$ \\
\hline FD $\neq>$ TO & $\mathbf{1 1 . 9 2}$ & $* * *$ & 9.58 & 6.35 & 4.73 \\
\hline TO $\neq>$ FD & 2.64 & & 9.43 & 6.05 & 4.66 \\
\hline & & & & & \\
\hline FD $\neq>$ GDP & 2.24 & & 9.33 & 6.12 & 4.66 \\
\hline GDP $\neq>$ FD & $\mathbf{2 2 . 6 5}$ & $* * *$ & 9.55 & 6.01 & 4.65 \\
\hline \multicolumn{1}{|l|}{} & & & & 4.67 \\
\hline GDP $\neq>$ TO & $\mathbf{1 6 . 8 9}$ & $* * *$ & 9.54 & 6.08 & 4.76 \\
\hline TO $\neq>$ GDP & $\mathbf{1 0 . 7 8}$ & $* * *$ & 9.57 & 6.31 & \\
\hline $\begin{array}{l}\text { f> implies non Granger causality. The optimal lags in VAR(p) model was determined based on SBC. The bootstrap critical values were } \\
\text { calculated based on 10,000 replications. *** indicates statistical significance at 1 percent.. }\end{array}$ \\
\hline
\end{tabular}

\section{Table 3: Linear causality analysis}

The findings indicate uni-directional causality from trade openness to financial development. With respect to causal linkages between economic growth and financial development, the results show that the causality runs from economic growth to financial development. Thereby, the nature of causation between economic growth and financial development support evidence on the demand-following hypothesis. As regards to causality between trade openness and economic growth, there is bi-directional causality between economic growth and trade openness, which proves support on the feedback hypothesis.

One drawback of linear causality methods is the possibility of overlooking nonlinear relations. It is thereby important to investigate nonlinear causal linkages among the variables of interest. In that respect, we conduct the DP nonlinear causality analysis. The nonlinear Granger causality analysis is carried out in two steps (Bekiros and Diks, 2008). In the first, the DP test is applied to the stationary series to detect nonlinear interrelationships. In the second step, the DP test is reapplied to the filtered VAR residuals to see whether the nature of causation is strictly nonlinear. After removing linear causality with a VAR model, any causal linkage from one residual series 
to another can be considered as nonlinear predictive power (Hiemstra and Jones, 1994: 1648). Note that the results for the DP test are discussed for one lag.

Table 4 present the results from the nonlinear causality test. The DP test on raw data indicates that there is a nonlinear causality from financial development to trade openness, which is consistent with linear causality analysis. Even though the nonlinear causality test implies a nonlinear feedback from financial development to trade openness, the DP test should be reapplied to filtered VAR residuals to see whether this causality is strictly nonlinear in nature (Bekiros and Diks, 2008: 1647). The results for the DP test on the VAR residuals substantiate the findings from raw data. Hence, the nonlinear analysis provides evidence on significant and persistent nonlinear causal linkage from financial development to trade openness in Turkey.

\begin{tabular}{|l|l|l|l|l|l|l|}
\hline & \multicolumn{2}{|l|}{ Raw data $^{\mathrm{a}}$} & \multicolumn{2}{l|}{ VAR residuals } \\
\hline
\end{tabular}

Table 4: Nonlinear causality analysis

When we look at nonlinear causal linkages between economic growth and financial development, it seems that there is bi-directional nonlinear causality from economic growth to financial development. Furthermore, this nonlinear causality appears to be strict due to the fact that the nonlinear causality based on the VAR residuals rejects the null hypothesis of nonlinear non-causality. The finding from nonlinear causality analysis between economic growth and financial development is thereby consistent with that from the linear causality test, implying the demand-following hypothesis. The nonlinear causal linkages between trade openness and economic growth analysis show that there is nonlinear causality from trade openness to economic growth. However, this causal linkage does not seem to be strictly nonlinear since the causality test from the VAR residuals does not show any causal linkage from trade openness to economic growth. Thereby, the nonlinear causality analysis provides weak evidence on the validity of the export-led growth hypothesis. This finding hence is particularly consistent with that from linear causality analysis. On the other hand, the nonlinear causality test supports evidence on the strict nonlinear causal linkage from economic growth to trade openness.

\section{Summary and Discussion}

This paper has empirically tested the causal linkages among trade liberalization, financial development and economic growth for Turkey. To this end, both linear and nonlinear approaches have been employed to detect the direction causality among the concerned variables by employing monthly data for the period January, 1989November, 2007.Empirical findings methodologically show that the nonlinear causality analysis captures all information provided by linear approach and furthermore it provides important information on whether the causal linkages among trade openness, financial development, and economic growth are in nature strictly nonlinear.

The non-linear analysis shows that trade liberalization causes economic growth (export-led growth), economic growth leads to financial development (demand-following) and financial development causes trade liberalization. These results provide empirical support for both the export-led growth and demand-following hypotheses. In addition, there is evidence on that financial development mobilizes resources to meet the need of trade sector. The results from the linear approach indicate that the relationship between trade and economic growth is rather bi-directional. In addition, the causality between both economic growth and financial development and financial development and openness is as in both nonlinear models. Specifically, economic growth causes financial development and financial development leads to trade liberalization.

Furthermore, keeping the analysis period (1989:M1-2007:M11) in mind, these findings partly support the view that economic growth depends upon trade through external finance in Turkey which has been experiencing capital account liberalization since 1989. Financial sector play a key role in this process. Sources of financial deepening may be both domestic as well as external. Whatever the sources, development in the financial markets seems to mobilize resources for the utilization of both import and export. The results imply that economic growth dependent upon trade seems to be sensitive financial development which may resulted from domestic and external sources. Although this paper does not focus on the sources of financial development whether domestic 
or external factors are dominant, it highlights the risk for sustainable economic growth if there is a lack or reverse of capital inflows which expand the domestic credit in Turkey.

\section{References}

- Acaravc1, A. Öztürk, İ. and Acaravc1, S. K., 2007. Finance- Growth Nexus: Evidence from Turkey. International Research Journal of Finance and Economics, 11,pp. 30-40.

- Acemoglu, D. Johnson, S. and Robinson, J. A., 2001. The Colonial Orijins of Comparative Development: An Empirical Investigation. American Economic Review, 91,pp. 1369-1401.

- Acemoglu, D. Johnson, S. and Robinson, J. A., 2004. Institutions as the Fundemental Cause of Long Run Growth. NBER Working Paper, No: 10481.

- Açıkgöz, Ş. Balcılar, M. and Saraçoğlu, B., 2009. Openness and Financial Development: Time Series Evidence From Turkey, Anadolu International Conference in Economics June 17-19, 2009, Eskişehir, Turkey.

- Aghion, P. Dewatripont, M. and Rey, P., 1997. Corporate Governance, Competition Policy and Industrial Policy. European Economic Review, 41,pp. 797-805.

- Ağır, H., 2010. Econometric Analysis of the Relationship Between Financial Liberalization and Financial Development, Banking Supervision and Regulation Agency, No.8., Ankara.

- Akçoraoğlu, A., 2000. Financial Sector and Economic Growth: An Exogeneity Analysis. Ankara University Journal of the Faculty of Political Sciences, 55(1), pp. 1-25.

- Altıntaş, H. and Ayrıçay, Y., 2009. An Analysis of the Relationship Between Financial Development and Economic Growth with the Approach of the Bonds Test: 1987-2007, X. Conference on Econometrics and Statistics, 27-29 May, Atatürk University (in Turkish).

- Andrianova, S. Demetriades, P. and Shortland, A., 2008. Government Ownership of Banks, Institutions and Financial Development, Journal of Development Economics, 85, pp. 218-252.

- Arestis, P. Demetriades, P. Fattouh, B. and Mouratidis, K., 2002. The Impact of Financial Liberalization Policies on Financial Development: Evidence From Developing Economies. International Journal of Finance and Economics, 7(2), pp. 109-121.

- Aslan, Ö. and Korap, H.L., 2006. Relationship Between Financial Development and Economic Growth in Turkey, Muğla University Journal of the Institute of Social Sciences, 17, pp. 1-20 (in Turkish)

- Aslan, Ö. and Küçükaksoy, İ., 2006. Relationship Between Financial Development and Economic Growth: An Econometric Application to the Turkish Economy, İstanbul University, Faculty of Economics, Journal of Econometrics and Statistics, 4, pp. 12-28 (in Turkish).

- Baek, E. and Brock, W., 1992. A General Test for Nonlinear Granger Causality: Bivariate Model. Working Paper. Iowa State University and University of Wisconsin-Madison; 1992.

- Bahmani-Oskooee, M. and Domaç, I.., 1995. Export Growth and Economic Growth in Turkey: Evidence from Cointegration Analysis, METU Studies in Development, 22(1), pp.67-77.

- Baltagi, B, Demetriades, P. and Law, S. H. (2009) Financial Development and Openness: Evidence from Panel Data. Journal of Development Economics, 89, pp. 285 - 296.

- Bao, Q. and Yang, J., 2007. Does Financial Development Promote International Trade? Frontiers of Economics in China, 2(4), pp. 532-557.

- Beck, T., 2002. Financial Development and International Trade Is There a Link? Journal of International Economics, 57, pp. 107-131.

- Bekiros, S.D. and Diks, C.G.H., 2008. The nonlinear dynamic relationship of exchange rates: parametric and nonparametric causality testing, Journal of Macroeconomics, 30, pp. 1641-1650.

- Ben Naceur, S. Boubakri, N. and Ghazouani, S. 2008. Privatization and Financial Market Development: A Comparison Between MENA Countries and Other Regions. Economic Research Forum, Working Paper No. 390.

- Bencivenga, V. and Smith, B., 1991. Financial Intermediation and Endogenous Growth. Review of Economic Studies, 58: 195-209.

- Bilgin, C. and Şahbaz, A., 2009. Causality Relations Between Growth and Export in Turkey, Journal of Social Sciences Gaziantep University, 8(1), pp. 177-198 (in Turkish).

- Bittencourt, M., 2008. Inflation and Financial Development: Evidence from Brazil. United Nations University, Research Paper No: 2008/14. 
- Blackburn, K. and Hung, V.T.Y., 1998. A Theory of Growth, Financial Development and Trade, Economica, 65, pp. 107-124.

- $\quad$ Brownbridge, M. Kirkpatrick, C.H. and Maimbo, S.M., 2005. "Financial Regulation in Developing Countries: Policy and Recent Experience", in C. Green, C. Kirkpatrick and V. Murinde (editors), Finance and Development Surveys of Theory, Evidence and Policy, Cheltenham, UK: Edward Elgar: 154-180.

- Chinn, M. and Ito, H., 2006. What Matters for Financial Development? Capital Controls, Institutions and Interactions. Journal of Development Economics, 81, pp. 163-192.

- Chinn, M.D. and Ito, H., 2002. Capital Account Liberalization, Institutions and Financial Development: Cross Country Evidence. NBER Working Paper Series, No: 8967.

- $\quad$ Creane, S. Goya, R. Mobarak, M. and Sab, R., 2003. Financial development and economic growth in the Middle East and North Africa. Finance and Development, 4(1).

- Cuadro, L. Gallego, S. and Herrero, A.G., 2003. Why Do Countries Develop More Financially than Others? The Role of the Central Bank and Banking Supervision. http://www.cass.city.ac.uk/conferences/emg_finance/Papers/Cuadro_Gallego_Garcia-Herrero.pdf $(12 / 12 / 2008)$.

- $\quad$ Cull, R. Senbet, L.W. and Sorge, M., 2001. Deposit Insurance and Financial Development, Policy Research Working Paper, WPS 2682: 1-61.

- $\quad$ Das, R.U. and Rishi, M., 2010 Are Trade Opennes and Financial Development Complementary? RIS Discussion Papers, 165.

- Demetriades, P.O., 2008. New Perspectives on Finance and Growth. University of Liecester, Working Paper No: 08/14.

- $\quad$ Di Giorgio, D., 1999. Financial Development and Reserve Requirements. Journal of Banking and Finance, 23, pp. 1031-1041.

- Dickey, D. and Fuller, W.A., 1979. Distribution of the Estimates for Autoregressive Time Series with Unit Root, Journal of the American Statistical Association, 74 (June), pp. 427-31.

- Dickey, D.A. and Fuller, W.A., 1979. Distribution of the Estimators for Autoregressive Time Series with a Unit Root. Journal of the American Statistical Society, 75, pp. 427-431.

- $\quad$ Diks, C. and Panchenko, V., 2005. A Note on the Hiemstra-Jones Test for Granger Non-causality. Studies in Nonlinear Dynamics and Econometrics, 9, pp. 1-7.

- $\quad$ Diks, C. and Panchenko V., 2006. A New Statistic and Practical Guidelines for Nonparametric Granger Causality Testing. Journal of Economic Dynamics and Control, 30, pp. 1647-1669.

- Do, Q.T. and Levchenko A.A., 2004. Trade and Financial Development, World Bank Policy Research Working Paper, No. 3347.

- Do, Q.T. and Levchenko, A.A., 2006. Comparative Advantage, Demand for External Finance and Financial Development. World Bank Policy Research Working Paper 3889, WPS 3889.

- Doğan, H., 2008. Relationship Between Finance and Real Economy in Turkey: Was Schumpeter Right?. Iktisat Issletme ve Finans, 23(272), pp. 49-79 (in Turkish).

- Doğanlar, M. and Fisunoğlu, M., 1999. Causality Between Exports and Economic Growth in Asian Countries. Yapı Kredi Economic Review, 10(11), pp. 3-11.

- Efron, B., 1997. Bootstrap Methods: Another Look at the Jackknife. Annals of Statistics, 7, pp.1-26.

- $\quad$ Feder, G., 1982. On Export and Economic Growth. Journal Of Development Economics, 12, pp. 59-73.

- Feeney, J., 1994. Goods and Asset Market Interdependence in a Risky World. International Economic Review 35, pp. 551-563.

- Ghatak, S. Milner, C. and Utkulu, U., 1995. Trade Liberalisation and Endogenous Growth: Some Evidence for Turkey, Economics of Planning, 28(2-3), pp. 147-167.

- Ginebri, S. Petrioli, G. and Sabani, L., 2001. Financial Deepening, Trade Openness and Growth: A Multivariate Cointegrated Analysis of the Complementary Effects, CIDEI Working Paper No. 62, Rome.

- Greenaway, D. and Milner, C., 1993. Trade and Industrial Policy in Developing Countries: A Manual of Policy Analysis, London: Macmillan.

- Greenwood, J. and Jovanovic, B., 1990. Financial Development, Growth and the Distribution of Income. Journal of Political Economy, 98(5), pp. 1076-1107. 
- Gries, T. Kraft, M. and Meierrieks, D., 2009. Linkages Between Financial Deepening, Trade Openness and Economic Development: Causality Evidence from Sub-Saharan Africa, World Development (37)12, pp. 1849-1860.

- Grossman, G. M. and Helpman, E., 1991. Quality Ladders in the Theory of Growth, Review of Economic Studies, 58, pp. 43-61.

- Grossman, G. M. and Helpman, E., 1992. Innovation and Growth in the Global Economy, Cambridge MA: MIT Press.

- Hacker, R. S. and Hatemi-J, A., 2006, Tests for Causality Between Integrated Variables Using Asymptotic and Bootstrap Distributions: Theory and Application. Applied Economics, 38, pp. 14891500 .

- Halıcıoğlu, F., 2007. Financial Development and Economic Growth Nexus For Turkey. MPRA Paper No. 3566, (http://mpra.ub.uni-muenchen.de/3566/, 10.06.2009).

- Hatemi-J, A. and Irandoust, M., 2000. Time-Series Evidence for Balassa's Export-Led Growth Hypothesis. Journal of International Trade and Economic Development, 9(3), pp. 355-365.

- Hermes, N., 1994. Financial Development and Economic Growth: A Survey of the Literature. Internationl Journal of Development Banking, 12(1), pp. 3-22.

- Hiemstra, C. and Jones, J. D., 1994. Testing for Linear and Nonlinear Granger Causality in the Stock Price-Volume Relation. Journal of Finance, 49(5), pp.1639-1664.

- Huang, W., 2006. Emerging Markets Financial Openness and Financial Development. University of Bristol, Discussion Paper No. 06/588. Department of Accounting and Finance, University of Bristol. Bristol.

- Huang, Y. and Temple, J., 2005. Does External Trade Promote Financial Development, University of Bristol, Discussion Paper, 05/575. Department of Economics, University of Bristol, Bristol.

- Hur, J. Raj, M. and Riyanto, Y.E., 2006. Finance and Trade: A Cross-Country Empirical Analysis on the Impact of Financial Development and Asset Tangibility on International Trade. World Development 34(10), pp. 1728-1741.

- Jalil, A. Feridun, M. and Ma, Y., 2010. Finance-Growth Nexus in China Revisited: New Evidence from Principal Components and ARDL Bounds Tests, International Review of Economics and Finance 19, pp. 189-195.

- Kar, M. and Ağır, H., 2006. Capital Markets, Financial Development and Economic Growth: The Turkish Case. İstanbul Üniversitesi, Journal of the Faculty of Economics, 56(1), pp. 13-46 (in Turkish).

- Kar, M. and Pentecost, E., 2000. The Direction of Causality Between Financial Development and Economic Growth in Turkey: Further Evidence. Economic Research Paper, Department of Economics, Loughborough University, No. 00/27. Loughborough.

- $\quad$ Kar, M., O. Peker ve Kaplan, M., 2008. Trade Liberalization and Financial Development and Economic Growth in the Long Run: the Case of Turkey. South East European Journal of Economics and Business, 3(2), pp. 25-38.

- $\quad$ King, R.G. and Levine, R., 1993. Finance and Growth: Schumpeter Might Be Right?. Quarterly Journal of Economics, 108(3), pp. 717-737.

- $\quad$ Klein, M.W. and Olivei, G.P., 2008. Capital Account Liberalization, Financial Depth and Economic Growth. Journal of International Money and Finance, 27, pp. 861-875.

- $\quad$ Kwiatkowski, D. Phillips, P.C.B. Schmidt, P. and Shin Y., 1992 Testing the Null of Stationarity Against the Alternative of a Unit Root: How Sure Are We That Economic Time Series Have a Unit Root?", Journal of Econometrics, 54, pp. 159-178.

- $\quad$ La Porta, R. Lopez-de-Silanes, F. and Shleifer, A., 2002. Government Ownership of Banks. Journal of Finance, 57(1), pp. 265-301.

- $\quad$ La Porta, R. Lopez-de-Silanes, F., Shleifer, A. and Vishny, R.W., 1997. Legal Determinants of External Finance. Journal of Finance, 52, pp. 1131-1150.

- $\quad$ Law, S. H. 2008. Does a Country’s Openness to Trade and Capital Flows Lead to Financial Development? Evidence from Malaysia. Asian Economic Journal, 22(2), pp. 161 - 177.

- $\quad$ Law, S. H. 2009. Trade Openness, Capital Inflows and Financial Development in Developing Countries. International Economic Journal, 23(3), 409 - 426 
- $\quad$ Law, S.H. ve Demetriades, P., 2006. Opennes, Institutions and Financial Development. Wold Economy \& Finance Research Programme Working Paper Series, WEF 0012, Economic \& Social Research Council.

- $\quad$ Levine, R., 1991. Stock Markets, Growth, and Tax Policy. The Journal of Finance; V(XLVI), pp. 14451465.

- $\quad$ Levine, R., 1997. Financial Development and Economic Growth: Views and Agenda. Journal of Economic Literature, 35, pp. 688-726.

- Lütkepohl, H., 2004. "Vector autoregressive and vector error correction models" in Lütkepohl, H. and Kratzig, M. (eds.) Applied Time Series Econometrics, Cambridge University Press: Cambridge.

- $\quad$ McKinnon, R.I., 1973. Money and Capital in Economic Development. Washington, D.C.: The Brooking Institution.

- Montiel, P.J., 2003. Development of Financial Markets and Macroeconomic Policy. Journal of African Economies, 12(2), pp. ii12-ii52.

- Nishimizu, M. and Robinson, A., 1986. "Productivity Growth in Manufacturing in Industrialisation and Growth: A Comparative Study” in H. Chenery, S. Robinson and M. Syrquin (eds.), Industrialisation and Growth, Oxford:Oxford University Press for World Bank.

- Özmen, E. and Furtun, G., 1998. Export-Led Growth Hypothesis and the Turkish Data: An Empirical Investication. METU Studies in Development, 25(3), pp. 491-503.

- Özmen, A, Özer, M. and Türkyılmaz, S., 1999. An Application Experience to the Causal Relations Between Export and Economic Growth. Dedication to Orhan Ŏguz, Marmara University Press, No. 640, pp.379-392.

- $\quad$ Öztürk, İ., 2008. Financial Development and Economic Growth: Evidence from Turkey. Applied Econometrics and International Development, 8(1), pp. 85-98

- $\quad$ Patrick, H. T., 1966. Financial Development and Economic Growth in Underdeveloped Countries. Economic Development and Cultural Change, 14, pp. 174-189.

- $\quad$ Pesaran, M. H. and Shin, Y., 1999. “An Autoregressive Distributed Lag Modeling Approach to Cointegration Analysis" in S. Strom (ed.), Econometrics and Economic Theory in the 20th Century, The Ragnar Frisch Centennial Symposium, Cambridge University Press, Cambridge, pp. 371-413.

- Pesaran, H. Shin, Y. and Smith, R.J., 2001. Bound Testing Approaches to the Analysis of Long Run Relationships. Journal of Applied Econometrics, 16(3), pp. 289-326.

- Phillips, P.C.B. and Peron, P., 1988. Testing for a Unit Root in Time Series Regression. Biomètrika, 75(2), pp. 336-346.

- Quah, D. and Rauch, J.E., 1990. Openness and the Rate of Economic Growth, Working Paper, University of California.

- $\quad$ Rajan, R.G. and Zingales, L., 2003. The Great Reversals: The Politics of Financial Development in the Twentieth Centurt. Journal of Financial Economics, 69, pp. 5-50.

- $\quad$ Redding, S., 1997. Dynamic Comparative Advantage and the Welfare Effects of Trade, Nuffield College Economics Discussion Paper, no. 140.

- Renelt, D., 1991. Economic Growth: A Review of the theoretical and Empirical Literature, Working Papers WPS 678, Washington, D.C.: World Bank.

- Renelt, D., 1991. Economic Growth: A Review of the theoretical and Empirical Literature. Working Papers WPS 678, Washington, D.C.: World Bank.

- $\quad$ Romer, P.M., 1986. Increasing Returns And Long Run Growth. Journal Of Political Economy, 94(5), pp.1002-1037.

- $\quad$ Saint-Paul, G., 1992. Technological Choice, Financial Markets and Economic Development. European Economic Review; 36(4), pp. 763-781.

- $\quad$ Saci, K. and Holden, K., 2008. Evidence on Growth and Financial Development Using Principal Components, Applied Financial Economics, 18(19), pp. 1549 - 1560.

- Schumpeter, J.A., 1912. The Theory of Economic Development, Cambridge: Harvard University Pres.

- Shaw, E.S., 1973. Financial Deepening in Economic Development, New York: Oxford University Pres.

- Şıklar, İ., 1992. Financial Development and Economic Growth in Turkey. Anadolu University Yearbook of Afyon Faculty of Economics and Administrative Sciences, pp.159-182 (in Turkish). 
- Şimşek, M., 2003. An Analysis of the Export-Led Growth Thypothesis with the Data of the Turkish Economy, 1960-2002. Dokuz Eylül University, Journal of the Faculty of Economics and Administrative Sciences, 18(2), pp. 43-63 (in Turkish).

- Svaleryd, H., Vlachos, J., 2002. Markets for Risk and Openness to Trade: How Are They Related? Journal of International Economics, 57, pp. 369-395.

- Svaleyrd, H. and Vlachos, J., 2000. Does Financial Development Lead to Trade Liberalization?, Department of Economics, Research Papers in Economics, No:2000:11, Stockholm University.

- $\quad$ Taşdemir, M., 2008. Estimating Monthly GDP for Turkey by State-Space Approach. International Research Journal of Finance and Economics, 17, pp. 144-151.

- $\quad$ Taylor, M.S., 1994. Once-off and Continuing Gains From Trade, Review of Economic Studies, 61, pp. 589-601.

- $\quad$ Toda, H.Y. and Yamamoto, T., 1995. Statistical Inference in Vector Autoregression with Possibly Integrated Processes. Journal of Econometrics, 66, pp.225-250.

- $\quad$ Tuncer, İ., 2002. Export, Import and Growth in Turkey: Granger Causality Analysis with the TodaYamamoto Approach (1980-2000). Çukurova University Journal of the Institute of Social Sciences, 9(9), pp. 90- 106 (in Turkish).

- Ünalmış, D., 2002. The Causality Between Financial Development and Economic Growth: The Case of Turkey. CBRT Research Department, Working Paper No: 3, Ankara. http://www.tcmb.gov.tr/research/work/wp6.pdf 25.01.2009.

- Utkulu, U. and Kahyaoğlu, H., 2005. To What Direction Did Trade and Financial Opennesses Affect Growth in Turkey?, Turkish Economic Association Discussion Papers 2005/13 (in Turkish).

- Yiğidim, A. and Köse, N., 1997. The Relationship Between Export and Economic Growth, the Effects of Import: The Turkish Case (1980-1996). Ekonomik Yaklaşım, 8(26), pp. 71-85.

- Yücel, F., 2009. Causal Relationships Between Financial Development, Trade Openness and Economic Growth: The Case of Turkey. Journal of Social Sciences 5(1), pp. 33-42. 